\title{
19. DIATOMS AT SITE 717, LEG 116
}

\author{
Irena Kaczmarska²
}

\begin{abstract}
Autochthonous marine pelagic and allochthonous coastal and freshwater diatoms were encountered in five samples from the Ocean Drilling Program (ODP) Leg 116 Holes 717A, 717B, and 717C. Allochthonous diatoms were transported to the equatorial Indian Ocean from inland locations and coastal waters, respectively.

The pelagic diatom assemblage consists mainly of warm and/or tropical diatoms known from the Neogene to Holocene. A stratigraphic marker, Rhizosolenia praebergonii var. robusta, which indicates Pliocene-Pleistocene (2.4-1.55 Ma) age of the sediments, was present in the samples from Core 116-717C-27X. Species composition of the whole assemblage is most similar to the tropical Indian Ocean Diatom Zone 6 of Schrader and supports an estimated age of 1.8-2.1 Ma for the sediments.
\end{abstract}

Approximately 100 samples were investigated for the presence of diatoms in the Bengal Fan sediments, ODP site 717. Diatom remnants were present in a number of samples, but their occurrence was rare. Samples with highest frequencies of diatoms were cleaned following the standard cleaning procedure (Kaczmarska, 1976) and then fractionated in heavy liquid (Kotlarczyk and Kaczmarska, 1988). Only five samples yielded diatom frustules in quantities and qualities suitable for further analysis; two samples from the uppermost strata at Holes 717A and 717B (Samples 116-717A-1H-2, 50-52 cm, -717B-1H-CC, 0-2 cm) and three samples from Hole 717C (116-717C-27X-1, 50-54 cm, -717C-27X-2, 3-8 cm, and -717C$27 \mathrm{X}-3,3-8 \mathrm{~cm})$. The samples and taxa encountered are listed in Table 1. Species composition in all these samples is very similar.

Diatom assemblages comprise several floristic elements of different ecological signature. Freshwater diatoms were represented by isolated specimens of Cymbella affinis, Epithemia adnata v. proboscioidea, E. turgida, Gomphonema parvulum v. micropus, Melosira granulata, Rhopalodia gibba, and Synedra ulna. More common were benthic coastal (shelf) diatoms such as several species of the genus Diploneis, Navicula hennedyi, Rhaphoneis amphiceros v. geminifera, Trachyneis aspera, and Triceratium favus. Most diversified and numerous, however, were representatives of neritic and oceanic plankton: Actinocyclus spp., Chaetoceros spp. (mostly present as resting spores), Coscinodiscus spp., Thalassiosira spp., Thalassionema nitzschioides s.l. and Thalassiothrix spp.

Several stratigraphically useful taxa present at Site 717 (Actinocyclus ellipticus, A. ellipticus f. lanceolata, Azpeitia nodulifera, Hemidiscus cuneiformis, Nitzschia marina, and Thalassiosira oestrupii) are known from sediments of late Neogene to Holocene.

Further refinement of the age determination is possible due to consistent occurrence of Rhizosolenia praebergonii var. robusta in the samples from the Core 116-717C-27X. The diatom is reported from low-latitude sediments of age circa 2.4-1.55 Ma (Barron, 1985). This assignment supports Pliocene-Pleistocene age inferred from calcareous nannofossils (Cochran, Stow, et al., 1989). The time span of circa

\footnotetext{
${ }^{1}$ Cochran, J. R., and Stow, D.A.V., 1990. Proc. ODP, Sci. Results, 116: College Station, TX, U.S.A. (Ocean Drilling Program).

2 Department of Biology, Mount Allison University, Sackville, N.B. E0A $3 \mathrm{CO}$, Canada.
}

2.4-1.55 Ma corresponds to tropical Indian Ocean Diatom (TID) Zones 7, 6 (2.1-2.4 Ma and 1.8-2.1 Ma, respectively, Schrader, 1974) and partially Zone 5 (approximately $1.8-1.2$ Ma) at the DSDP Sites 238, 215, and 213. All these sites are located at approximately $10^{\circ} \mathrm{S}$, and clearly away from the Bengal Fan influence. Schrader (1974) characterizes diatom flora of the TID Zones 5 and 6 as essentially modern and comparable to TID Zone 4 where the most common diatoms were: Actinocyclus ehrenbergii, A. divisus, A. ellipticus f. lanceolata, Asterolampra affinis, A. marylandica, Asteromphalus arachne, $A$. flabellatus, $A$. heptactis, $A$. imbricatus, Azpeitia africana (= Coscinodiscus africanus), A. nodulifera (= Coscinodiscus nodulifer), Coscinodiscus crenulatus, C. lineatus, C. lineatus v. ellipticus, C. tabularis v. egregius, Ethmodiscus rex, Hemidiscus cuneiformis, Nitzschia marina, $N$. seriata, N. reinholdii, Pseudoeunotia doliolus, Roperia tesselata, Rhizosolenia bergonii, Pleurosigma sp., Thalassosira eccentrica, Th. oestrupii, Th. plicata, Thalassionema nitzschioides, Thalassiothrix fraunfeldii, and Thal. longissima.

Floral elements of the TID 7 (Schrader, 1974) are as follows: Actinocyclus ellipticus, Asterolampra marylandica, Asteromphalus imbricatus, Azpeitia a fricana, $A$. nodulifera, Coscinodiscus lineatus, $C$. plicatus, C. tabularis v. egregius, Ethmodiscus rex, Hemidiscus cuneiformis, Nitzschia fossilis, $N$. interrupta, $N$. marina, $N$. seriata, $N$. reinholdii, Roperia tesselata, Rhizosolenia bergonii, Rhiz. praebergonii v. robusta (Barron, 1985), Thalassiosira convexa, Th. eccentrica, Th. plicata, Th. symbolophora, Th. oestrupii, Thalassiosira sp. 7, Thalassiosira sp. VII, Thalassionema nitzschioides, Thalassiothrix longissima, and Thal. frauenfeldii.

Inspection of Table 1 clearly indicates that the diatoms present in the Core 116-717C-26X and -27X samples have as many species in common with the TID Zones 5 and 6 as with the TID Zone 7. Comparison of the frequencies of the taxa however, indicates that the taxa absent in Hole $717 \mathrm{C}$ are rare or quantified as few in the TID Zones 5-7 (Schrader, 1974). Moreover, all diatoms listed as common and/or abundant at the DSDP Sites 238, 215, and 213 TID Zones 6 and 7 are present and relatively frequent in the Core $116-717 \mathrm{C}-27 \mathrm{X}$ sediments. Thus, I postulate that the diatom assemblage retrieved from Core $116-717 \mathrm{C}-27 \mathrm{X}$ corresponds broadly to TID Zones 6 and/or 7, which represent a time span of approximately $1.8-2.4 \mathrm{Ma}$ Considering further, however, only 

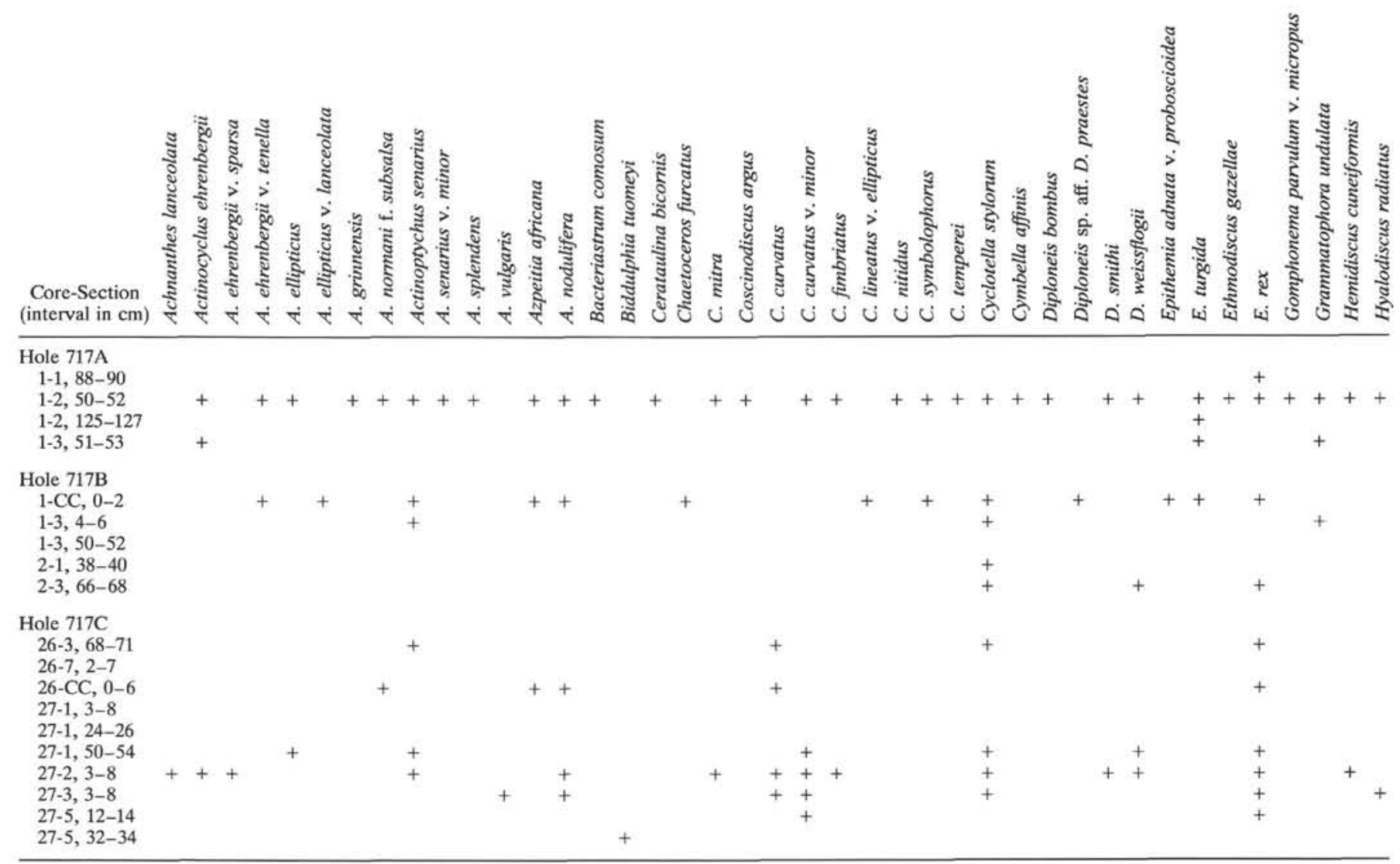

the negative evidence, that is an absence of Pseudoeunotia doliolus (its appearance designates the top of TID Zone 6 and beginning of Zone 5) and Thalassiosira convexa (its extinction marks top of the TID Zone 7 and beginning of the Zone 6) the Core $116-717 \mathrm{C}-27 \mathrm{X}$ diatom assemblage may be correlated to TID Zone 6 (circa 1.8-2.1 Ma) of Schrader (1974).

Two samples from Holes 717A and 717B (Samples 116$717 \mathrm{~A}-1 \mathrm{H}-2,50-52 \mathrm{~cm}$, and -717B-1H-CC, 0-2 cm) contain the same diatom assemblage as the sediments from the Core 116-717C-27X. Considering their lithostratigraphic position and the presence of Rhizosolenia praebergonii var. robusta, diatom remnants in these samples are most likely redeposited.

\section{TAXONOMIC LIST}

For taxonomic identifications the following publications were used: Cleve-Euler (1968), Desikachary and Devi (1986), Desikachary, Gowthaman, and Latha (1987), Fenner (1977), Fenner, Schrader, and Wenigk (1976), Hasle (1977), Patrick and Reimer (1975), Ramirez (1981), Schrader (1974), Schrader and Fenner (1976), SheshukovaPoretzkaia (1967), and Sieminska (1964).

Achnanthes lanceolata (Breb.) Grun. Actinocyclus ehrenbergii Ralfs

A. ehrenbergii var. sparsa (Greg.) Hust.

A. ehrenbergii var. tenella (Breb.) Hust.

A. ellipticus Grun.

A. ellipticus f. lanceolata Kolbe

A. grinnensis Azp.

A. normani f. subsalsa (Juhl.-Dannf.) Hust.

Actinoptychus senarius (Ehr.) Ehr.
A. senarius var. minor $\mathrm{A}$. $\mathrm{Cl}$. A. splendens (Shadb.) Ralfs

A. vulgaris Schum.

Azpeitia africana (Jan.) G. Fryx. et Watkins

A. nodulifera (A. Schmidt) G. Fryx. et Sims

Bacteriastrum comosum Pavillard

Biddulphia tuomeyi (Bail.) Rop.

Cerataulina bicornis (Ehr.) Hasle

Chaetoceros furcatus Ehr.

C. mitra (Bail.) Cl.

Coscinodiscus argus Ehr.

C. curvatus Grun.

C. curvatus var. minor (Ehr.) Grun.

C. fimbriatus Ehr.

C. lineatus Ehr.

C. lineatus var. ellipticus Kolbe

C. nitidus Greg.

C. symbolophorus Grun.

C. temperei Brun.

Cyclotella stylorum Bright.

Cymbella affinis Kuetz.

Diploneis bombus Ehr.

Diploneis sp. aff. D. praestes (A.S.) Cl.

D. smithi (Breb.) Cl.

D. weissflogii (Schmidt) Cl.

Epithemia adnata (Kuetz.) Breb. var. proboscioidea (Kuetz.) Patr.

E. turgida (Ehr.) Kuetz.

Ethmodiscus gazellae (Jan.) Hust.

E. $\operatorname{rex}$ (Wal.) Hend., fragments only

Gomphonema parvulum (Kuetz.) Grun. var. micropus (Kuetz.) 
Table 1 (continued).

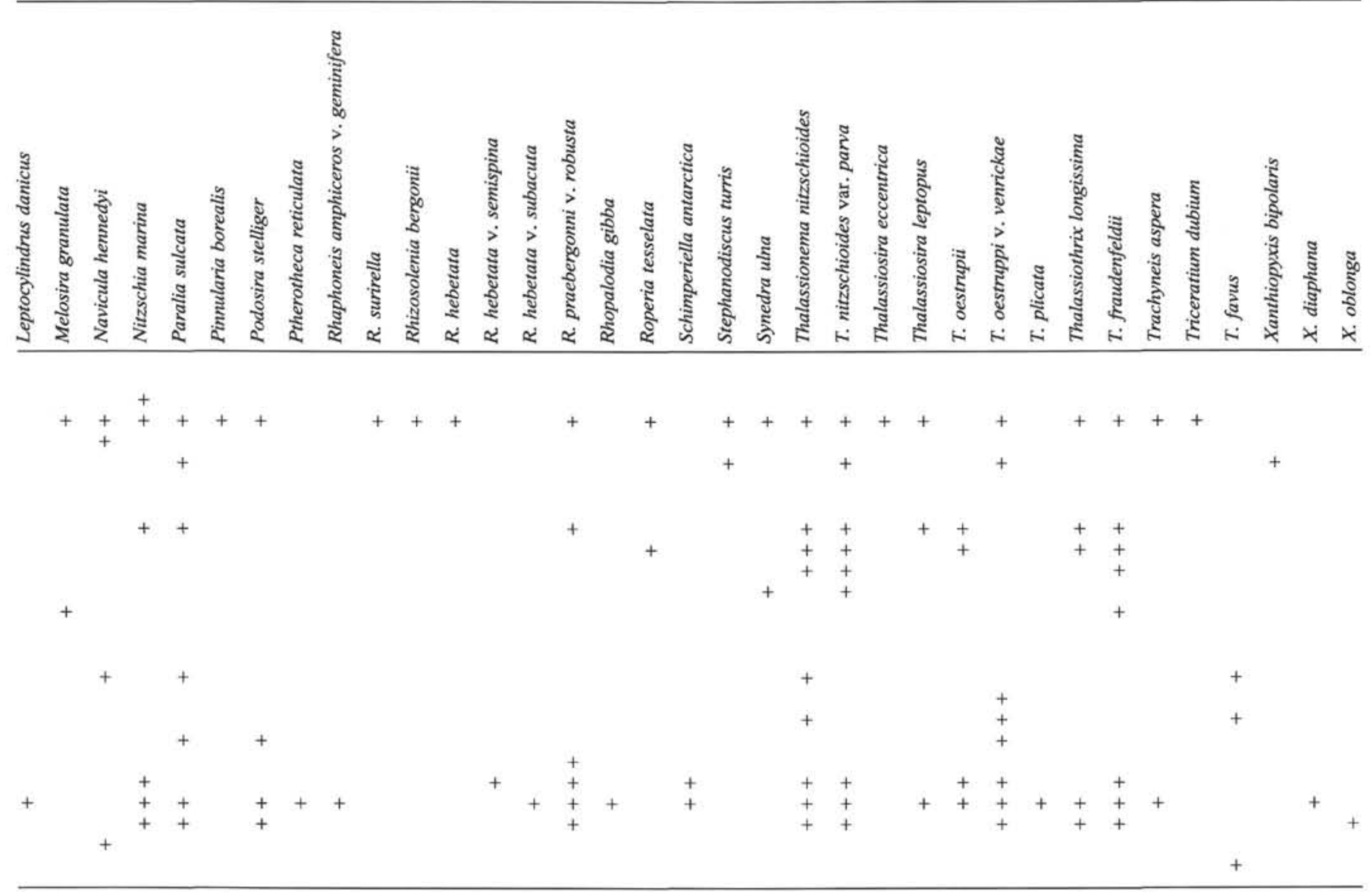

Grammatophora undulata Ehr.

Hemidiscus cuneiformis Wallich

Hyalodiscus radiatus (O'Maera) Grun.

Leptocylindrus danicus $\mathrm{Cl}$.

Melosira granulata (Ehr.) Ralfs

Navicula hennedyi W. Sm.

Nitzschia marina Grun.

Paralia sulcata (Ehr.) Cl.

Pinnularia borealis Ehr.

Podosira stelliger (Bail.) Mann

Pterotheca reticulata Sheshuk.

Rhaphoneis amphiceros Ehr. var. geminifera (Ehr.) Perag.

$R$. surirella (Ehr.) Grun.

Rhizosolenia bergonii Peragallo

$R$. hebetata (Bail.) Grun.

$R$. hebetata var. semispina (Hensen) Gran

$R$. hebetata var. subacuta Grun.

$R$. praebergonii Mukhina var. robusta Burckle et Trainer

Rhopalodia gibba (Ehr.) O. Mull.

Roperia tesselata (Rop.) Grun.

Schimperiella antarctica Karst.

Stephanodiscus turris Ralfs

Synedra ulna (Nitzsch.) Ehr.

Thalassionema nitzschioides Grun.

$T$. nitzschioides var. parva Heiden

Thalassiosira eccentrica (Ehr.) $\mathrm{Cl}$.

T. leptopus (Grun.) Hasle et G. Fryx.

T. oestrupii (Ost.) Hasle

T. oestrupii var. venrickae G. Fryx. et Hasle

T. plicata Schrader

Thalassiothrix longissima $\mathrm{Cl}$.

T. fraudenfeldii Grun.

Trachyneis aspera (Ehr.) $\mathrm{Cl}$.
Triceratium dubium Bright.

T. favus Ehr.

Xanthiopyxis bipolaris Lohm.

$X$. diaphana Forti

$X$. oblonga Ehr.

\section{ACKNOWLEDGMENTS}

Participation in the Leg 116 cruise and this study are supported by the NSERC CSP grant 0020234, "Neogene paleoceanography at the ODP Leg 116 and 119, a North-south transect in the Indian Ocean."

Jim M. Ehrman read the manuscript and his linguistic comments are greatly appreciated. My thanks are also extended to G. A. Fryxell and D. A. Stockwell for reviewing the manuscript and offering valuable comments.

\section{REFERENCES}

Barron, J. A., 1985. Miocene to Holocene planktic diatoms. In Bolli, H. M., Saunders, J. B., and Perch-Nielsen, K. (Eds.), Plankton Stratigraphy: Cambridge (Cambridge Univ. Press), 763-809.

Cleve-Euler, A., 1968. Die Diatomeen von Schweden und Finnland. K. Svenska Vetensk. Akad., Handl., Fjarde Serien, 2(1): 1-162, 4(1) 1-158, 4(5) 1-255, 5(4) 1-232, 3(3) 1-153. In Bibliotheca Phycologica: Lehre (J. Cramer).

Cochran, J. R., Stow, D.A.V., et al., 1989. Proc. ODP, Init. Repts., 116: College Station, TX (Ocean Drilling Program).

Desikachary, T. V., and Devi, K.A.R., 1986. Marine fossil diatoms from India band Indian Ocean. In Desikachary, T. V. (Ed.), Atlas of Diatoms: Madras (Madras Sci. Found.), Plates 1-77.

Desikachary, T. V., Gowthaman, S., and Latha, Y., 1987. Diatom flora of some sediments from the Indian Ocean region. In Desika- 
chary, T.V. (Ed.), Atlas of Diatoms: Madras (Madras Sci. Found.), Plates 78-221.

Fenner, J., 1977. Cenozoic diatom biostratigraphy of the equatorial and southern Atlantic Ocean. In Perch-Nielsen, K., Supko, P. R., et al., Init. Repts. DSDP, Suppl. to Vol. 39, 40, and 41: Washington (U.S. Govt. Printing Office), 491-624.

Fenner, J., Schrader, H. J., and Wienigk, H., 1976. Diatom phytoplankton studies in the southern Pacific Ocean, composition and correlation to the Antarctic Convergence and its paleoecological significance. In Hollister, C. D., Craddock, C., et al., Init. Repts. DSDP, 35: Washington (U.S. Govt. Printing Office), 757-813.

Hasle, G. R., 1977. Morphology and taxonomy of Actinocyclus normanii f. subsalsa (Bacillariophyceae). Phycologia, 16:321-328.

Kaczmarska, I., 1976. Diatom analysis of Eemian profile in freshwater deposits at Imbramowice near Wroclaw. Acta Paleobot., 17:3-33.

Kotlarczyk, J., and Kaczmarska, I., 1988. The two horizons with the Oligocene and Lower Miocene diatoms from the Polish Outer Carpathians. Ann. Sci. Geol. Poloniae, 57:143-189.

Patrick, R., and Reimer, C. W., 1975. The Diatoms Of The United States (Vol. 2): Philadelphia (Acad. Nat. Sci. Philadelphia).
Ramirez, P. R., 1981. Beitrage zur Taxonomie und Verbreitung der Gattung Thalassiosira Cleve: Lehre (J. Cramer).

Schrader, H.-J., 1974. Cenozoic marine planktonic diatom stratigraphy of the tropical Indian Ocean. In Fisher, R. L., Bunce, E. T., et al., Init. Repts. DSDP, 24: Washington (U.S. Govt. Printing Office), 878-967.

Schrader, H.-J., and Fenner, J., 1976. Norwegian Sea Cenozoic diatom biostratigraphy and taxonomy. In Talwani, M., Udintsev, G., et al., Init. Repts. DSDP, 38: Washington (U.S. Govt. Printing Office), 921-1099.

Sheshukova-Poretzkaia, W. S., 1967. Neogenovyie morskie diatomovyie vodorosli Sakhalina $i$ Kamtschatki: Leningrad (Izdat. Leningrad Univ.).

Sieminska, J., 1964. Chrysophyta II, Bacillariophycaea, Okrzemki. In Starmach, K. (Ed.), Flora Slodkowodna Polski: Warszawa (Polskie Wydawnictwo Naukowe).

Date of receipt: 28 March 1989

Date of initial acceptance: 17 January 1990

Ms 116B-128 